\title{
Microstructural and Process Parameters of aluminium alloys Using FSW
}

\author{
Nuzhat Nazira, Manish Kumar Gupta ${ }^{\mathrm{b}^{*}}$

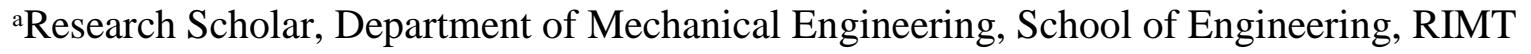 \\ University, Mandigobindgarh, Punjab, India - 147301 \\ ${ }^{\mathrm{b}}$ Assistant Professor, Department of Mechanical Engineering, School of Engineering, RIMT \\ University, Mandigobindgarh, Punjab, India - 147301 \\ *Corresponding Email ID: manishgupta@rimt.ac.in
}

\begin{abstract}
Friction stir welding (FSW) has become a popular method for connecting low weight metals. Material joining occurs in the solid state in FSW. Inserting a rotating tool travelling over the faying surfaces of the material to be bonded is used to complete the procedure. It produces practically defect-free welds with little distortion and a fine grain structure. However, the welding mechanism and process parametric combination for welds with consistent and dependable outcomes are not well understood. The thesis details the experimental efforts made to suggest an optimal combination of parameters with simple tool geometry for FSW at greater linear speeds. The materials for research were two precipitation hardenable aluminium alloys: 6mm thick 2219-T87 and 5083H321. The influence of process parameters on weld microstructural changes and defect development was also examined. The optimal combination of process parameters for the FSW of aluminium alloys was proposed, and the most relevant parameter for weld strength and quality was discovered.
\end{abstract}

Keywords: FSW, Distortion, microstructural, process parameters, aluminium alloys, 2219T87, 5083H321

\section{INTRODUCTION}

Aluminium is a soft, lightweight metal with scope of appearances based on the surface roughness, ranging from grey to silvery. Aluminium and its alloys outperform mild steel in terms of strength. To pick the best product, several criteria like as corrosion resistance, electrical conductivity, machinability, and aesthetics are considered. These alloys have melting temperatures ranging from 482 to $660^{\circ} \mathrm{C}$. It is also non-toxic. These alloys characteristics are produced by solution heat treatment and quenching, followed by natural or artificial ageing. These alloys get extra strength by being cold worked. The 2xxx, 6xxx, and $7 \mathrm{xxx}$ series are heat treatable alloys. The hardening impact of alloying components such as 
silicon, iron, manganese, and magnesium determines the strength of non-heat treated aluminium alloys. Strain hardening may enhance the strength of all non-heat treated alloys. The 1xxx, 3xxx, 4xxx, and 5xxx series, depending on their primary alloying constituents, are non-heat treatable alloys. Aluminum alloy 2219 (Al-6.5\%) is a popular age-hardenable alloy used in aerospace applications all over the world. It is mostly due to its outstanding weldability properties. The aluminium alloy 2219 includes around 5.8 percent to 6.8 percent copper, as well as trace quantities of manganese, titanium, and vanadium. Due to the lack of a ductile-to-brittle transition and high cryogen resistance, this alloy is widely employed in cryogenic applications. High strength ( $\mathrm{YS}=387 \mathrm{MPa}$ to $471 \mathrm{MPa}$ in various ageing circumstances) and strong resistance to stress corrosion cracking are other features of the alloy. Although the yield strength of the weld metal is significantly lower in the as welded condition, i.e. 120 to $140 \mathrm{MPa}$, as reported by several sources, the alloy2219 is regarded to have high weldability. The difference in strength between the base metal and the weld metal, particularly the yield strength values, is substantial, necessitating design engineers to employ thicker base metal plates, which increases the structure's total weight. This is an issue in aircraft applications since the usage of thicker plate's results in a reduced payload owing to the poor yield strength of the weld metal. This is especially beneficial when post-weld heat treatment is either impossible or difficult to do. About 4.5 percent to $5 \% \mathrm{Mg}$ is included in the aluminium alloy 5083, along with minor quantities of other alloying elements. The Al-Mg alloys of the 5xxxseries are mostly utilised in the shipbuilding industry, where low weight is important. The major alloying ingredient in the 5000series is magnesium. These alloys are strain hardenable, relatively high strength alloys with exceptional toughness and corrosion resistance, even in seawater. FSW is a solid-state welding technique that produces no radiation or harmful gases and prevents solidification cracking and porosity. The method has been continuously refined and its field of application increased since its inception. Friction Stir welding combines deformation heating and mechanical action to produce high-quality, defect-free connections. It's especially well-suited to connecting aluminium alloys in a variety of plate thicknesses, and it outperforms fusion welding when it comes to fusing highalloyed aluminium. The pin and shoulder of a non-consumable rotating tool are placed into the butting edges of plates to be connected and moved along the joint line. Because of the combined impact of the tool rotating speeds and the traverse speed, the joint is formed in a solid state, with the material moving from the front to the rear of the pin. For the welding of different aluminium alloys, solid-state welding techniques are appropriate. Friction stir welding (FSW) is one of the most popular solid-state welding techniques for joining 
dissimilar aluminium alloys because it can produce welds in a number of joint configurations, including butt joints. The aluminium alloys Al-Cu alloy AA2219 and Al-Mg alloy AA5083 are both widely utilised in the aerospace and marine sectors. In this research an attempt to look at the FSW of AA2219-T87 to AA5083-H321. Any fusion welding technique will not be able to combine dissimilar aluminium alloys 2219 (Al-Cu) and 5083 (Al-Mg), owing to the presence of 6.5 percent $\mathrm{Cu}$ and 4.5 percent $\mathrm{Mg}$, respectively, in these alloys. Friction stir welding, being a solid state welding technique, has a lot of potential in this area. The major goals of this research are to generate sound welded joints, optimise welding settings, and perform metallurgical characterization of various weld zones, in order to investigate a novel way of getting sound welded connections between 2219 and 5083 alloys. It is feasible to study and comprehend the flow of material during friction stir welding since two distinct materials are being connected. Understanding the corrosion behaviour of the welded joint, particularly the stir zone where two distinct aluminium alloys are combined, is also of importance. The following are the goals of this research project. (a)To use the friction stir welding technique to generate defect-free welds between the aluminium alloys AA2219 and AA5083,(b)Evaluation of the mechanical characteristics of the joint (tensile and hardness),(c)Joint tensile characteristics are used to optimise friction stir welding parameters (rotational speed, welding speed, shoulder to pin diameter ratio, and pin profiles),(d)Weld metallurgical characterization to determine structure-property relationships,(e) Evaluation of weld pitting and corrosion behaviour in general.The basic materials for this investigation were aluminium alloys 2219-T87 and 5083-H321. In the early stages of this project, $5 \mathrm{~mm}$ plates were utilised to improve several parameters. The majority of this was done on plates with a thickness of $6 \mathrm{~m}$. Welds were made on two distinct materials, AA2219 and AA5083, using friction stir welding. The microstructures of the weld zone and the mechanical characteristics of the welds were studied in depth. In this study, microstructural investigations using optical microscopy, SEM, and EPMA were deemed necessary. The purpose of the optical microstructural investigations was to look at the solidification structure in the weld zones. The EPMA research aimed to investigate and compare the amount of $\mathrm{Cu}$ and $\mathrm{Mg}$ segregation in the weld zone. The $\mathrm{Cu}$ and $\mathrm{Mg}$ in the weld zone were evaluated using the SEM-EDX, as well as fractography. The precipitation of the strengthening phases was studied using TEM (Transmission Electron Microscopy) to determine the reasons for weld zone strengthening. The scope of mechanical property evaluation included tensile testing at room temperature. The weld metal hardness was also to be assessed in order to see how the weld fusion zones reacted to ageing treatments. It was predicted that when the microstructure 
and chemical composition of the welds changed in the process of increasing mechanical characteristics, the corrosion behaviour would change as well. Dynamic polarization experiments were used to assess the pitting corrosion resistance of the weld zones.

\section{METHODLOGY}

In this research the experiments that were carried out for this study covers the materials, welding techniques and settings, as well as the mechanical characteristics and chemical compositions of the basic materials. The mechanical testing methodologies and characterization techniques used to assess the welds are also discussed in depth. Figures 1 and 2 illustrate the experimental set up of the friction stir welding machine and the friction stir welding procedure. To produce these welds, the majority of this research was done on 2219-87 and 5083-321 aluminium alloys with a thickness of $6 \mathrm{~mm}$ (figure 3). Initially, 5mm thick plates were utilised to determine the best welding settings. (Table1) lists the chemical compositions of the basic materials utilised in this investigation. The figures in the table represent the average of at least three investigations utilising X-Ray spectral analysis. (Table 2) lists the mechanical characteristics of the aluminium alloys 2219 and 5083. The table represent the average of at least three studies.

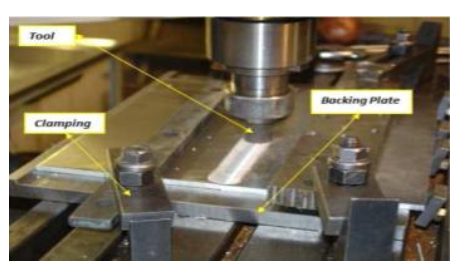

Figure 1: Friction stir Welding Machine Figure 2 Friction stir welding process

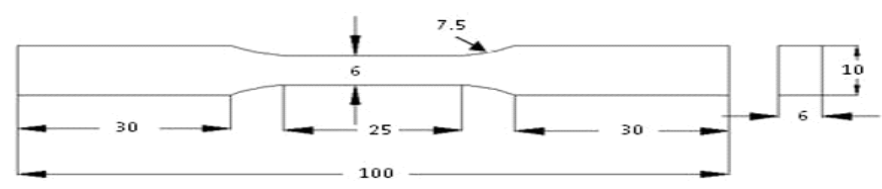

Figure 3: Dimensions of the tensile specimen (mm) 
Table 1: Chemical composition of the base material (weight \%)

\begin{tabular}{|c|c|c|c|c|c|c|}
\hline Material & Mg & Mn & Fe & Sr & Cu & Al \\
\hline AA5083 & 4.15 & 0.73 & 0.31 & 0.13 & 0.025 & Remaining \\
\hline AA2219 & 0.01 & 0.27 & 0.13 & 0.01 & 6.7 & Remaining \\
\hline
\end{tabular}

\section{RESULTS AND DISCUSSION}

The majority of this research was done on $6 \mathrm{~mm}$ thick 2219-T87 and 5083H321 aluminium alloy plates. (Table 2) shows the tensile characteristics of the aluminium alloys 2219 and 5083. The figures in the table represent the average of at least three studies.

Table 2: Mechanical properties of the base materials AA5083 and AA2219

\begin{tabular}{|c|c|c|c|}
\hline Base metal & $\begin{array}{c}\text { 0.2\% Proof } \\
\text { strength (MPa) }\end{array}$ & $\begin{array}{c}\text { Ultimate tensile } \\
\text { strength(MPa) }\end{array}$ & \% Elongation \\
\hline AA5083 - H321 & 225 & 303 & 28 \\
\hline AA2219- T87 & 387 & 471 & 20 \\
\hline
\end{tabular}

FRICTION STIR WELDING OF 2219 - 2219

Friction stir welding tests were done using different Friction stir welding settings gathered from the literature. Friction stir welding was performed with the following process parameters (Rotational speed - $800 \mathrm{rpm}$, Welding speed - $40 \mathrm{~mm} / \mathrm{minute}$, Shoulder diameter to pin diameter - 3) to provide defect-free, high-quality welds. These procedure parameters were obtained using a trial and error technique. The cross-sectional macrostructures of the friction stir welded aluminium alloys 2219 are shown in (Figure 4). In the weld, there were three different microstructural zones: Stir Zone or Weld Nugget (Stirred Zone), Thermo Mechanically Affected Zone (TMAZ), and Heat-Affected Zone (HAZ). The stir zone is not shaped like a basin or an ellipse, which are the two most frequent stir zone forms.

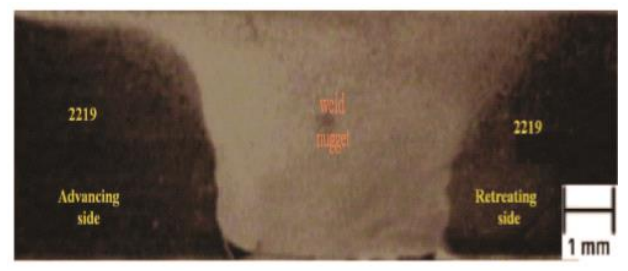

Figure 4: Macrostructures of welded material 


\section{Micro Structure}

It inclides the study of basic materials included grains that were elongated in the rolling direction as well as a significant number of eutectic and intermetallic particles. On both sides of the Thermo Mechanically Affected Zone, there were severely deformed grains, with obvious boundaries between the Stirred Zone/Thermo Mechanically Affected Zone and the Thermo Mechanically Affected/HeatAffected Zone. There were no significant changes in grain structure in the Heat Affected Zone (HAZ) on either side of the weld nugget compared to the corresponding unaffected base materials. The base material of 2219, $\mathrm{CuAl}$, was discovered to be larger in size than those in the nugget, as shown in Figure 5, and the microstructure of the HAZ zone is shown in (Figure 6), (Figure 7) shows fragmentation of particles in the stirred zone. In the agitated zone, the number of particles per unit area is observed to be greater. There is no indication of dissolving of the $\mathrm{CuAl} 2$ eutectic particles, which may be explained by the fact that peak temperatures in the weld nugget during friction stir welding

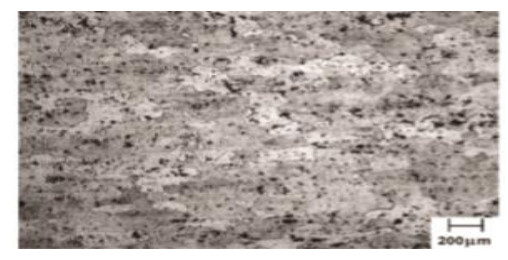

Figure 5: Microstructures of base materials AA2291

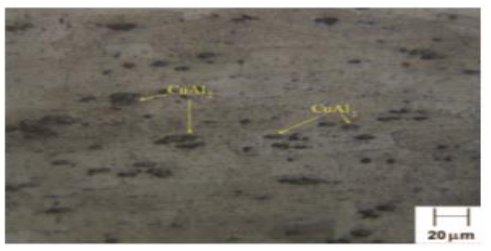

Figure 6: Microstructures of HAZ (2219-2219)

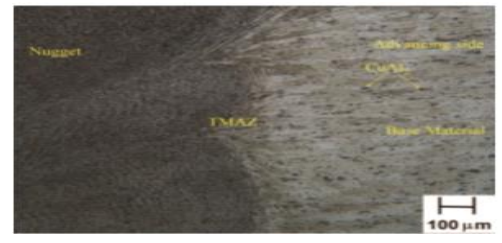

Figure 7: Microstructures of weld Nugget and TMAZ (2219-2219)

\section{Micro Hardness}

Vickers micro hardness tests were performed throughout the weld (mid-section, $1 \mathrm{~mm}$ spacing) to determine any microstructure/property changes across the weldment. (Figure 8) 
depicts the results graphically. As can be observed, the hardness of the 2219 undamaged base material dropped significantly near the weld nugget border. The hardness of the weld nuggets was much lower than that of the 2219 base material. This might be attributed to the partial or complete dissolving of strengthening precipitates, as well as the loss of work hardening action as a result of the high temperatures. For the same reasons, HAZ and TMAZ exhibit a substantial decrease in hardness. The decrease of strength is due to the dissolving of hardening precipitates. Aside from that, region-specific hardness values (Table 3) are determined, and the average hardness values are linked to the fracture location with the macrostructure of failed tensile specimens (Figure 9). The nugget area, where tensile failures occur, has the lowest hardness values among the welded specimens.

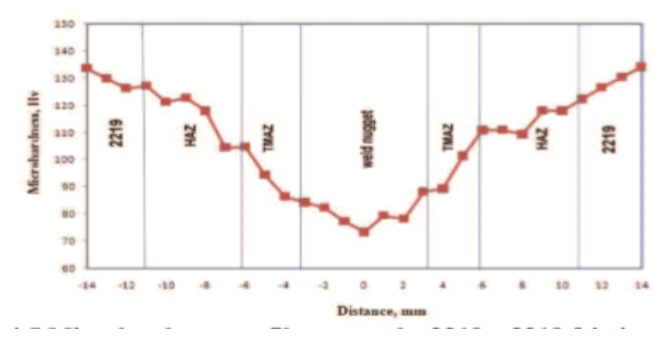

Figure 8: Microhardness profile across the 2219-2219 friction stir welding

Table 3: Microhardness profile across the 2219-2219 friction stir welding

\begin{tabular}{|l|l|l|l|l|l|l|}
\hline \multicolumn{3}{|c|}{ Advancing side 2219 } & \multicolumn{3}{|c|}{ Retreating side 2219 } \\
\hline BASE & HAZ & TMAZ & NUGGET & TMAZ & HAZ & Base \\
\hline 131.2 & 109.1 & 113.3 & 106.7 & 115.9 & 111.2 & 130.1 \\
\hline 129.8 & 110.8 & 111.5 & 108.3 & 112.9 & 108.1 & 132.4 \\
\hline 128 & 117.8 & 111.9 & 94.1 & 106.3 & 104.4 & 126.4 \\
\hline 118.6 & 119.3 & 113.2 & 107 & 112.9 & 117.8 & 126.9 \\
\hline 128.1 & 117.4 & 105.8 & 108.7 & 118.2 & 109.6 & 127.8 \\
\hline 122.8 & 111.6 & 114.9 & 107.8 & 117.2 & 113.3 & 120.4 \\
\hline 122.1 & 108.4 & 107.8 & 93.8 & 112.3 & 111.2 & 121.2 \\
\hline 119.9 & 121.2 & 113.3 & 102.6 & 109.6 & 117.8 & 126.4 \\
\hline 124.4 & 116.8 & 115.9 & 106.1 & 104.9 & 119.3 & 121.9 \\
\hline $122 \_3$ & 120.2 & 120.1 & 98.2 & 112.3 & 120.5 & 122.6 \\
\hline 127.4 & 115.4 & 111.4 & 102.4 & 109.6 & 108.3 & 128.4 \\
\hline 126.8 & 113.6 & 109.2 & 105.2 & 114.2 & 117.6 & 127.6 \\
\hline Average Hardness Value \\
\hline 125.12 & 113.13 & 112.36 & 103.41 & 112.19 & 113.26 & 126.01 \\
\hline
\end{tabular}

\section{Tensile Test}

The friction stir welded coupons in welded condition were used to make transverse tensile specimens with a gauge length of $25 \mathrm{~mm}$ and a width of $6 \mathrm{~mm}$ (total length: $100 \mathrm{~mm}$ ). On a universal tensile testing equipment, room temperature tensile tests were performed on sets of 
three samples per welding condition in accordance with ASTM E8. (Table 4) shows the results of weld transverse tensile testing. The nugget region of the welded specimens failed in all three weld instances. (Figure 9) depicts the macrostructure of the failed tensile test specimen. In comparison to the base material, the friction stir welds had reduced strength and percent elongation. Joint efficiency was determined to be 54.5 percent in relation to proof stress and 52.6 percent in relation to UTS. The joint efficiency obtained in 2219 friction stir welds is lower than that obtained in several other heat treatable alloys

Table 4: Results of FSW tensile testing specimens of AA2219

\begin{tabular}{|c|c|c|c|c|}
\hline \multicolumn{5}{|c|}{ Results of FSW tensile testing specimens of AA2219 } \\
\hline $\begin{array}{c}\text { Material/ } \\
\text { condition }\end{array}$ & $\begin{array}{c}\text { 0.2\%Proof } \\
\text { strength } \\
\text { (MPa) }\end{array}$ & $\begin{array}{c}\text { Ultimate Tensile } \\
\text { strength (MPa) }\end{array}$ & $\begin{array}{c}\text { Elongation } \\
(\%)\end{array}$ & $\begin{array}{c}\text { Failure } \\
\text { location }\end{array}$ \\
\hline $\begin{array}{c}\text { AA2219 T87 } \\
\text { (Base metal) }\end{array}$ & 387 & 471 & 20 & \\
\hline $\begin{array}{c}2219-2219 \\
\text { (weld joint) }\end{array}$ & 211 & 248 & 11 & weld nugget \\
\hline
\end{tabular}

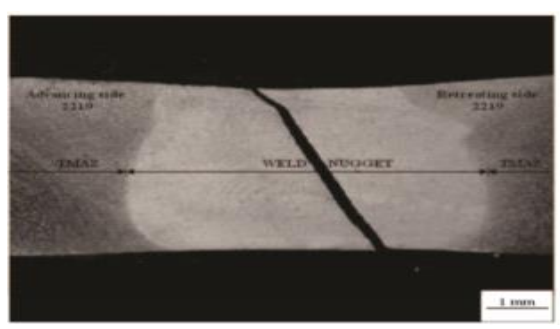

Figure 9: Macrostructures of 2219-2219 FSW failed sample

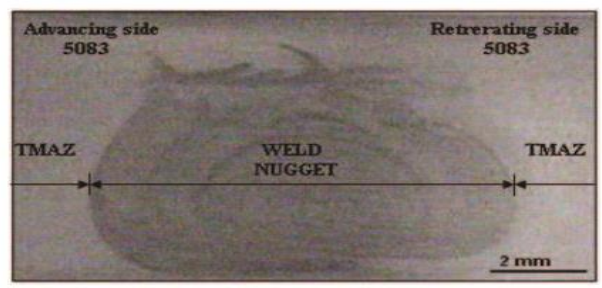

Figure 10: Macrostructures of welded materials

\section{Pitting Corrosion of FSW Aluminium Alloys 2219 - 2219}

(Table 5) shows the pitting potential values of the friction stir welds AA2219-AA2219.The pitting potential values of the 2219 -T87 base metal (advancing side Epit $=-720.57$, retreating side Epit $=-709)$ and the friction stir weld nugget $($ Epit $=-684)$ are noticeably different, and this is the cause for the weld nugget's lack of precipitates and phase. The eutectic particles present in the weld metal appear to be less hazardous than the particles due to the eutectic particles considerably lower copper concentration. The weld nugget's pitting 
corrosion resistance has improved noticeably, as seen by lower negative Epit values. Pitting potential values represent the potential at which pitting begins, with smaller negative values indicating greater pitting corrosion resistance.

Table 5: Pitting potential values of FSW aluminum alloys 2219-2219

\begin{tabular}{|c|c|}
\hline Material & Pitting Potential $\mathbf{E}_{\mathbf{p i t}}(\mathbf{m V})$ \\
\hline $2219-$ T87 base metal & $-640 \mathrm{mV}$ \\
\hline $2219-2219$ weld nugget & $-684 \mathrm{mV}$ \\
\hline TMAZ/HAZ advancing side & $-720 \mathrm{mV}$ \\
\hline TMAZ/HAZ retreating side & $-709 \mathrm{mV}$ \\
\hline
\end{tabular}

\section{FRICTION STIR WELDING OF 5083 - 5083}

On 5083 plates, many friction stir welding trials were carried out using the trial-anderror approach, with the welds being evaluated for soundness and tensile characteristics. The following process settings were found to produce welds with satisfactory mechanical characteristics (Rotational speed $550 \mathrm{rpm}$, Welding speed-30 mm/minute, Ratio of shoulder diameter to pin diameter - 3).

\section{Macro Structure}

The cross-sectional macrostructures of the friction stir welded sound joints in aluminium alloys 5083 were created without voids, fractures, or distortion, as shown in Figure 10. The stir zone was formed like a basin and seemed more like a rectangular box, with no macroscopic defects or weakly bonded areas visible in the weld region, which spanned the whole thickness of the plates.

\section{Micro Structure}

As illustrated in (Figure 11), the base material utilised in this investigation contains a number of undissolved second-phase intermetallic particles, which were identified as iron/manganese aluminide particles. There were no noticeable changes in the microstructure on either side of the weld nugget in the HAZ when compared to the respective unaffected base material, and while the nugget region appeared darker due to etching, there was little difference in the microstructures of the nugget and the base metal (Figure 12). This is due to the fact that the grain boundaries of these alloys could not be properly etched. At greater magnifications, however, close examination reveals that the nugget area contains finer recrystallized grains. 


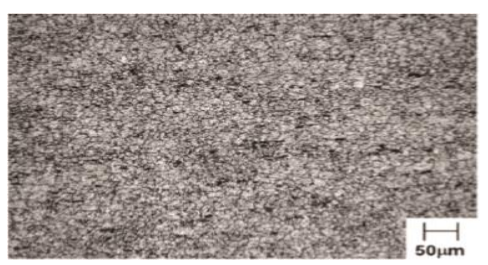

Figure 11: Microstructures of base materials AA5083

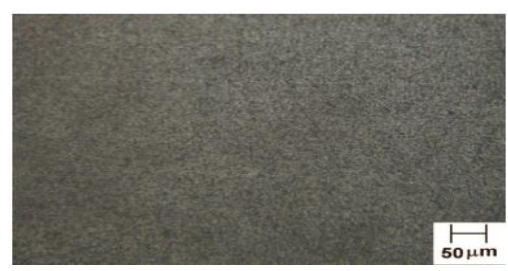

Figure 12: Microstructures of weld nugget $(5083-5083)$

\section{Micro Hardness}

Microhardness tests were conducted across the weld (midsection, $1 \mathrm{~mm}$ spacing) to ascertain the possible microstructure/property variations across the various regions of the weldment. The results are pictorially shown in (Figure13). The weld nugget showed a higher hardness values compared to the base material as the HAZ and TMAZ. Apart from this, region wise hardness values are found out (Table 6) and the average hardness values are correlated to the fracture location with the macrostructure of the failed tensile specimens (Figure 14). Lowest hardness values of the welded specimens are in HAZ of retreating side where the tensile failures take place.

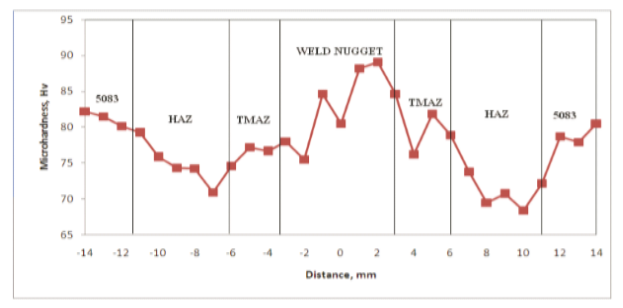

\section{Figure 13: Microhardness profile across the weld}

Apart from this, region wise hardness values are found out (Table 6) and the average hardness values are correlated to the fracture location with the macrostructure of the failed tensile specimens (Figure14). Lowest hardness values of the welded specimens are in HAZ of retreating side where the tensile failures take place 
Table 6: Microhardness of the 5083 - 5083 friction stir weld

\begin{tabular}{|l|l|l|l|l|l|l|}
\hline \multicolumn{3}{|l|}{ Advancing side 5083 } & & \multicolumn{3}{c|}{ Retreating side 5083 } \\
\hline BASE & HAZ & TMAZ & NUGGET & TMAZ & HAZ & BASE \\
\hline 71.6 & 76.7 & 79.7 & 82.1 & 87.1 & 66.6 & 78.8 \\
\hline 75.7 & 68.2 & 80.5 & 92.4 & 83.6 & 72.2 & 77.9 \\
\hline 78.2 & 76.5 & 76.6 & 90.5 & 76.1 & 69.3 & 80.5 \\
\hline 81.5 & 67 & 74.8 & 88.8 & 73.1 & 71.7 & 75.8 \\
\hline 80.1 & 74.3 & 75.5 & 89.9 & 74.5 & 70.5 & 77.3 \\
\hline 79.2 & 65.9 & 78 & 89.1 & 78.9 & 68.4 & 75.1 \\
\hline 75.8 & 68.6 & 79.4 & 84.6 & 76.2 & 67.9 & 74.3 \\
\hline 78.9 & 67.6 & 77.2 & 84.6 & 73.8 & 65.3 & 78.4 \\
\hline 82.2 & 73.7 & 79.3 & 96.6 & 75.3 & 68.3 & 78.8 \\
\hline 77.4 & 70.6 & 73.6 & 99.9 & 80.5 & 69.5 & 84.3 \\
\hline 81.2 & 67.1 & 74.6 & 81.8 & 73.2 & 66.1 & 75.7 \\
\hline 78.7 & 65.5 & 75.5 & 80.9 & 72.6 & 65.7 & 79.7 \\
\hline Average Hardness Value \\
\hline 78.38 & 70.14 & 77.06 & 88.43 & 77.16 & 68.46 & 78.05 \\
\hline
\end{tabular}

\section{Tensile Test}

Weldcoupons in as-welded state were used to make transverse tensile specimens with a gauge length of $25 \mathrm{~mm}$ and a breadth of $6 \mathrm{~mm}$ (total length: $100 \mathrm{~mm}$ ). Three samples were tensile tested at room temperature using an ASTM E8 universal tensile testing equipment. (Table 7) shows the results of weld transverse tensile testing. The heat affected zone of the retreating side failed all three welded specimens, and the macrostructure of the failed tensile test specimen is illustrated in (Figure14). In comparison to the base material specimens, the weld specimens had somewhat reduced strength. When it comes to proof strength, the joint efficiency is 100 percent, and when it comes to UTS, it's about $90 \%$. The excellent ductility of the 5083-5083 friction stir welds is another noteworthy result. This is due to the fact that the hardness variations across the three weld areas, nugget, TMAZ, and HAZ, are negligible under stress. In contrast, as mentioned in the previous section, the 2219 friction stir welds have significantly lower ductility (11 percent). The huge difference in hardness between nugget and TMAZ/HAZ was the major reason for this. As a result, distortion in the nugget region is localised, resulting in low percent elongation of the joint in the instance of 2219.

Table 7: Results of FSW tensile testing specimens of AA5083

\begin{tabular}{|l|l|l|l|l|}
\hline $\begin{array}{l}\text { Material } \\
\text { /Condition }\end{array}$ & $\begin{array}{l}\text { 0.2\% } \\
\text { strength }(\mathrm{MPa})\end{array}$ & $\begin{array}{l}\text { Proof } \\
\text { strength }(\mathrm{MPa})\end{array}$ & $\begin{array}{l}\text { Elongation } \\
(\%)\end{array}$ & $\begin{array}{l}\text { Failure } \\
\text { location }\end{array}$ \\
\hline
\end{tabular}




\begin{tabular}{|l|l|l|l|l|}
\hline $\begin{array}{l}\text { AA5083 - H321 } \\
(\text { Base metal })\end{array}$ & 255 & 303 & 28 & - \\
\hline $\begin{array}{l}5083-5083 \\
(\text { Weld joint })\end{array}$ & 255 & 286 & 22 & Weld nugget \\
\hline
\end{tabular}

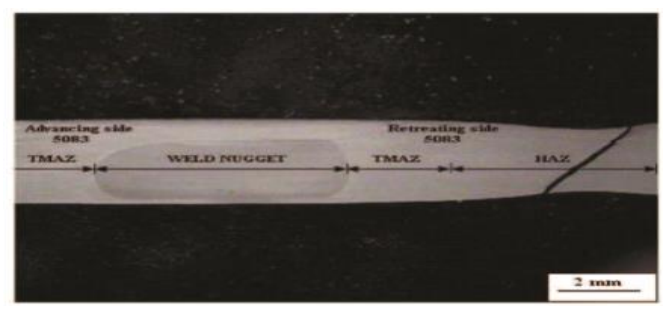

Figure 14: Macrostructures of 5083-5083 FSW failed sample

\section{Pitting Corrosion of FSW Aluminium Alloys 5083 - 5083}

(Table 8) shows the pitting potentials of friction stir welds AA5083AA5083. The pitting potential values of the friction stir weld nugget and the AA5083 base metal differ significantly. Pitting corrosion resistance is reduced in the nugget. This might be because there are more Al-Fe-Mn intermetallic particles present. (Figure11) shows that while there were fewer second phase particles in the base metal, their size was larger. However, as seen in (Figure12), the nugget has a greater number of tiny particles of smaller size. During the stirring process, these particles fragment, resulting in a nugget with a greater number of smaller particles and hence lower pitting potentials. The TMAZ on both sides of the nugget has a severely distorted and strained grain structure, which reduces pitting corrosion resistance even further.

Table 8: Pitting potential values of FSW aluminum alloys 5083-5083

\begin{tabular}{|l|l|}
\hline Material & Pitting Potential Epit (mV) \\
\hline $5083-\mathrm{H} 321$ base metal & $-523 \mathrm{mV}$ \\
\hline $5083-5083$ weld nugget & $-558 \mathrm{mV}$ \\
\hline TMAZ/HAZ advancing side & $-573 \mathrm{mV}$ \\
\hline TMAZ/HAZ retreating side & $-563 \mathrm{mV}$ \\
\hline
\end{tabular}




\section{FRICTION STIR WELDING OF 2219-5083}

Friction stir welding in a butt arrangement was performed with a commercially available friction stir welder and various welding process settings. These process parameters were chosen using the optimization tool (MINITAB 15). For friction stir welding, AA2219 plate was put on the advancing side and AA5083 plate on the retreating side. The pin was put in the middle of the joint line.

\section{Parameters for Welding Optimization}

The Taguchi L16 orthogonal design of trials was used to optimise the process parameters. The factors studied for this research include rotating speed, transverse speed, tool pin geometry, and the ratio between the tool shoulder diameter and pin diameter $(\mathrm{D} / \mathrm{d})$. The tensile strength of the friction stir welded joint is used to identify the best procedure parameters. The projected optimal tensile strength value is validated by running a confirmation run using the best parameters. This research indicates that a wide variety of process parameters may be used to generate defect-free, high-efficiency welded joints, and it suggests the settings that provide the best joint tensile characteristics.

Table 9: Process parameters values and their four levels

\begin{tabular}{|l|l|l|l|l|}
\hline Level & Tool pin geometry (A) & $\begin{array}{l}\text { Rotational } \\
\text { speed } \\
(\mathbf{r p m})(\mathbf{B})\end{array}$ & $\begin{array}{l}\text { Transverse speed } \\
(\mathbf{m m} / \mathbf{m i n})(\mathbf{C})\end{array}$ & $\begin{array}{l}\text { D/d ratio } \\
(\mathbf{D})\end{array}$ \\
\hline Level 1 & Straight cylinder & 400 & 15 & 1.5 \\
\hline Level 2 & Tapered cylinder & 550 & 30 & 2 \\
\hline Level 3 & Cylinder straight threaded & 700 & 45 & 3 \\
\hline Level 4 & Tapered cylinder threaded & 800 & 60 & \\
\hline
\end{tabular}

\section{Taguchi Method}

The major goal of parameter design was to optimise the settings of process parameter values in order to improve performance characteristics and to determine the product parameter values .Furthermore, the optimal process parameter values derived from the parameter design are intended to be immune to changes in environmental conditions and other noise sources. As a result, the Taguchi method's parameter design was a crucial step in achieving high quality without raising costs. The Taguchi technique, on the other hand, employs a unique design of orthogonal arrays to examine all of the parameters with the fewest possible experiments. Taguchi devised a loss function to determine the differences between the 
experimental and intended values. To assess performance characteristics that deviate from the target value, he suggests using the loss function. The loss function's value was then converted into a signal to noise $(\mathrm{S} / \mathrm{N})$ ratio. There were three kinds of performance characteristics for the S/N ratio analysis: the lowest the best, the highest the best, and the nominal the best.

\section{CONCLUSIONS}

1. Aluminium is a soft, lightweight metal with surface roughness varying from grey to silvery. Aluminum is nonmagnetic and does not spark. It is also soluble in alcohol, but in certain forms it is also soluble in water.

2. Aluminium is about one-third the density and rigidity of steel. It's a pliable metal that can be drawn on, stamped on, and extruded. It is also resistant to corrosion because of a thin coating of aluminium oxide that develops on the metal's surface when exposed to air, preventing further oxidation.

3. Because of galvanic interactions with alloyed copper, the strongest aluminium alloys are less corrosion resistant. The bulk of this investigation was conducted on $6 \mathrm{~mm}$ thick 2219-T87 and 5083H321 aluminium alloy plates.

4. Friction stir welding experiments were conducted using different friction stir welding settings obtained from the literature.

5. To produce defect-free, high-quality welds, friction stir welding was conducted with the following process parameters (Rotational speed - $800 \mathrm{rpm}$,Welding speed - 40 $\mathrm{mm} /$ minute, Shoulder diameter to pin diameter - 3). These process parameters were determined via trial and error.

\section{REFERENCES}

[1] Amancio-Filho, S.T., Sheikhi, S., Dos Santos, J.F., Bolfarini, C. "Preliminary study on the microstructure and mechanical properties of dissimilar friction stir welds in aircraft aluminium alloys 2024-T351 and 6056-T4", Journal of materials processing technology, Vol. 206, pp. 132-142, 2008.

[2] ASTM E8/E8M - 09. "Standard test methods for tension testing of metallic materials1", ASTM International, 3 July 2010.

[3] Atallah, M.M. and Hanadi G Salem. "Friction stir welding parameters: a tool for controlling abnormal grain growth during subsequent heat treatment", Materials Science Engineering, Vol. 391, pp.51-59, 2004.

[4] Baeslack III, W.A., Jata, K.V., Lienert, T.J. "Structure, properties and fracture of friction stir welds in a high-temperature Al-8.5Fe-1.3V-1.7Si alloy (AA-8009)", J Mater sci., Vol. 41, pp. 2939-2951, 2006. 
[5] Bala Srinivasan, P., Dietzel, W., Zettler, R., dos Santos, J.F., Sivan, V. "Stress corrosion cracking susceptibility of friction stir welded AA7075-AA6056 dissimilar joint”, Materials Science and Engineering A, Vol. 392, pp. 292-300, 2005.

[6] Beathe Heinz., Birgit Skrotzi. "Characterization of a Friction-StirWelded Aluminum Alloy 6013", Metallurgical and materials transactions B, Vol. 33B, pp. 489-498, 2002.

[7] Bob Irving. "Scandium Places Aluminum Welding on a New Plateau", Welding Journal, 76, 1997, pp. 53-57.

[8] Brenneccke, M.W. "Electron beam welded heavy gage aluminium alloy 2219", Welding Journal, January, pp. 28-40s, 1965.

[9] Bruni, C., Forcellese, A., Gabrielli, F. and Simoncini M. "Effect of the /v ratio and sheet thickness on mechanical properties of magnesium alloy FSWed joints", Int J Mater Form, Suppl 1, Vol. 3. pp.1007-1010, 2010.

[10] Cavaliere, P., De Santis, A., Panella, F., Squillace, A. "Effect of welding parameters on mechanical and microstructural properties of dissimilar AA6082-AA2024 joints produced by friction stir welding", Materials and Design, Vol. 30, pp. 609-616, 2009.

[11] Cavaliere, P., Panella, F. "Effect of tool position on the fatigue properties of dissimilar 2024-7075 sheets joined by friction stir welding", Journal of Materials Processing Technology, Vol. 206, pp. 249-255, 2008.

[12] Chen, T. and Lin, W.B. "Optimal FSW process parameters for interface and welded zone toughness of dissimilar aluminium-steel joint", Science and Technology of Welding and Joining, Vol. 15, pp. 279-285, 2010.

[13] Chen, Y., Liu, H. and Jicai, F. "Friction stir welding characteristics of different heat treated state 2219 aluminium alloy plate", Materials Science and Engineering A, Vol. 420, pp. 21-25, 2006.

[14] Choi, D.H., Lee, C.Y., Ahn, B.W., Yeon, Y.M., Park, S.H.C., Sato, Y.S., Kokawa, H., Jung, S.B. "Effect of fixed location variation in friction stir welding of steels with different carbon contents", Science and Technology of Welding and Joining, Vol. 15, pp.299-304, 2010.

[15] Cristiano Padovani, Alison J Davenport., Brian J Connolly., Stewart W Williams., EirianSiggs., AmelaGroso., Marco Stampanoni. "Corrosion protection of AA7449T7951 friction stir welds by laser surface melting with an Excimer laser", Corrosion Science, Vol. 53, pp. 3956-3969, 2011.

[16] D'Urso G., Giardini, C. "The influence of process parameters and tool geometry on mechanical properties of friction stir welded aluminium lap joints", Int J Mater Form, Vol.3 Suppl 1, 1011 - 1014, 2010.

[17] Da Silva, A.A.M., Arruti, E., Janeiro, G., Aldanondo, E., Alvarez, P., Echeverria, A., "Material flow and mechanical behaviour of dissimilar AA2024-T3 and AA7075-T6 aluminium alloys friction stir welds", Materials and Design, Vol. 32, pp. 2021-2027, 2011.

[18] Datta, S., Bandyaopadhyay, A. and Pal, P.K. "Application of Taguchi Philosophy for Parametric Optimization of Bead Geometry and HAZ Width in Submerged Arc Welding Using a Mixture of Fresh Flux and Fused Flux", International Journal of Advanced Manufacturing Technology, Vol. 36, pp. 689-698, 2008.

[19] Elangovan, K. and Balasubramanian, V. "Influences of tool pin profile and welding speed on the formation of friction stir processing zone in AA2219 aluminium alloy", Journal of materials processing technology, Vol. 200, pp. 163-175, 2008. 
[20] Elangovan, K. and Balasubramanian, V. "Influences of pin profile and rotational speed of the tool on the formation of friction stir processing zone in AA2219 aluminium alloy", Materials Science Engineering A, Vol. 459, pp. 7-18, 2007.

[21] Elangovan, K., Balasubramanian, V. and Babu, S. "Developing an Empirical Relationship to predict Tensile strength of friction stir welded AA2219 aluminium alloy", Journal of Material Engineering and performance, Vol. 17, No. 6, pp. 820$830,2008 \mathrm{a}$

[22] Elangovan, K., Balasubramanian, V., Valliappan, M. "Influences of tool pin profile and axial force on the formation of friction stir processing zone in AA6061 aluminium alloy", Int J Adv ManufTechnol, Vol. 38, pp. 285-295, 2008 b.

[23] Fisher, R.A. "Statistical methods for research worker", Olive and Boyd, London, 1925.

[24] Fonda, R. W. and Lambrakos, S. G. "Analysis of friction welds using inverse problem approach", Science and Technology Joining, Vol. 7, No. 3, pp. 177 -181, 2002.

[25] Fujii, H., Cui, L., Maeda, M., and Nogi, K. "Effect of Tool Shape on Mechanical Properties and Microstructure of Friction Stir Welded Aluminum Alloys", Materials Science and Engineering A, Vol. 419, pp. 25-31, 2006.

[26] Ghosh, M., Kumar, K., Kailas, S.V., Ray, A.K. "Optimization of friction stir welding parameters for dissimilar aluminum alloys”, Materials and Design, Vol. 31, pp. 30333037, 201

[27] Hartman, J.A., Beil, R.J. and Hahn, G.T. " Effect of copper rich region on tesile properties of VPPA weldments of 2219-T87 aluminium", Welding Journal, pp. 7383s, 1987.

[28] Hirata, T., Oguri, T., Hagino, H., Tanaka, T., Chung, S.W., Takigawa, Y. and Higashi, K. "Influence of Friction Stir Welding Parameters on Grain size and formability in 5083 Aluminium Alloy", Materials Science and Engineering A, Vol. 456, pp. 344-349, 2006.

[29] Jamshidi Aval, H., Serajzadeh, S., Kokabi, A.H. "Evolution of microstructures and mechanical properties in similar and dissimilar friction stir welding of AA5086 and AA6061”, Materials Science and Engineering A, Vol. 528, pp. 8071- 8083, 2011.

[30] Jariyaboon, M., Davenport, A.J., Ambat, R., Connolly, B.J., Williams, S.W., Price, D.A. "The effect of welding parameters on the corrosion behaviour of friction stir welded AA2024-T351”, Corrosion Science, Vol. 49, pp. 877-909, 2007.

[31] Ju Kang., Rui-dong Fu., Guo-hong Luan., Chun-lin Dong. , Miao He. "In-situ investigation on the pitting corrosion behavior of friction stir welded joint of AA2024-T3 aluminium alloy", Corrosion Science, Vol. 52, pp. 620-626, 2010.

[32] Karthikeyan, R., Balasubramanian, V. "Predictions of the optimized friction stir spot welding process parameters for joining AA2024 aluminum alloy using RSM", Int J Adv ManufTechnol, Vol. 51, pp. 173-183, 2010.

[33] Khodir, S. A., Shibayanagi, T. "Friction stir welding of dissimilar AA2024 and AA7075 aluminum alloys", [J]. Materials Science and Engineering B, Vol. 148, pp. $8287,2008$.

[34] Kimapong, K. Watanabe, T. "Friction stir welding of aluminium alloy to steel", Welding Journal, Vol. 83, pp. 277s-282s, 2004.

[35] Kostka, A., Coelho, R.S., Dos Santos, J. and Pyzalla, A.R. "Microstructure of friction stir welding of aluminium alloy to magnesium alloy", Scripta Materialia, Vol. 60, pp. 953-956, 2009. 
[36] Koteswara Rao, S.R. "Effect of Grain Refinement, ThermoMechanical Treatments and Scandium Additions on the Mechanical Properties of AA2219 welds", PhD Thesis, 2005.

[37] Kumar, K. and Kailas, S.V. "Positional dependence of material flow in friction stir welding - an analysis of joint line remnant and its relevance to dissimilar metal welding", Science and Technology of Welding and Joining, Vol. 15, pp. 305-311, 2010.

[38] Kwon, Y.J., Shigematsu, I. and Satio, N. "Mechanical properties of fine-grained aluminium alloy produced by friction stir process", Scripta Materialia, Vol. 49, pp. 785-789, 2003

[39] Kwon, Y.J., Shigematsu, I., Saito, N. "Dissimilar friction stir welding between magnesium and aluminum alloys", Materials Letters Vol. 62, No. 23, pp. 3827-3829, 2008.

[40] Lakshminarayanan, K. and Balasubramanian, V. "Comparison of RSM with ANN in predicting tensile strength of friction stir welded AA7039 aluminium alloy joints", Transactions of Non Ferrous Metal Society of China, Vol. 19, pp. 9-18, 2009.

[41] Lakshminarayanan, K. and Balasubramanian V. "Process parameters optimization for friction stir welding of RDE-40 aluminium alloy using Taguchi technique", Transactions of Non Ferrous Metal Society of China, Vol. 18, pp. 548-554, 2008.

[42] Lathabai, S. and Lloyd, P.G. "The effect of scandium on the microstructure mechanical properties and weldability of a cast Al-Mg alloy", Acta Materialia, Vol. 50, pp. 4275-4292, 2002.

[43] Leal, R.M. and Loureiro, A. "Effect of overlapping friction stir welding passes in the quality of welds of aluminium alloys", Materials and Design, Vol. 29, pp. 982-991, 2008.

[44] Lee, W. B., Yeon, Y. M. and Jung, S. B. "Evaluation of the microstructure and mechanical properties of friction stir welded 6005 aluminium alloy", Material Science and Technology, Vol. 19, pp. 1513-1518, 2003b.

[45] Lee, W. B., Yeon, Y. M. and Jung, S. B. "The joint properties of dissimilar formed aluminium alloys by friction stir welding according to fixed location of materials", Scripta Materialia, Vol. 49, pp.423-428, 2003a.

[46] Leitao, C., Leal, R.M, Rodrigues, D.M., Loureiro, A., Vilaca, P. "Mechanical behaviour of similar and dissimilar AA5182-H111 and AA6016-T4 thin friction stir welds", Materials and Design, Vol. 30, pp. 101-108, 2009.

[47] Li, Y., Murr, L.E., McClure, J.C. "Solid-state flow visualization in the friction stir welding of 2024 Al to 6061 Al”, Scripta Materialia, Vol. 40, pp. 1041-1046, 1999.

[48] Liu, C., Chen, D.L., Bhole, S., Cao, X., Jahazi, M. "Polishing-assisted galvanic corrosion in the dissimilar friction stir welded joint of AZ31 magnesium alloy to 2024 aluminum alloy", Materials Characterization, Vol. 60, pp. 370-376, 2009.

[49] Liu, H. J., Fujii, H. and Maeda, M. "Tensile properties and fracture locations of friction stir welded joints of 2017 - T351 aluminium alloy", Journal of Material Processing anf Technology, Vol. 142, pp. 692-696, 2003.

[50] Lombard, H., Hattingh, D.G., Steuwer, A. and James, M.N. "Optimizing FSW process parameters to minimize defects and maximize fatique life in $5083-\mathrm{H} 321$ aluminium alloy", Engineering Fracture Mechanics, Vol. 75, pp. 341 -354, 2008.

[51] Lomolino, S., Tovo, R. and Dos Santos, J. "On the fatiquebehavior and design curves of friction stir butt welded Al alloys", International Journal of Fatique, Vol. 27, pp. 305-316, 2005. 
[52] Luijendijk, T. "Welding of dissimilar aluminium alloys", Journal of Materials Processing Technology, Vol. 103, pp. 29-35, 2000.

[53] Ma, Z.Y., Mishra, R.S. and Mahoney, M.W. "Superplastic deformation behaviour of friction stir processed 7075 Al alloy", Acta Mareialia, Vol. 50, No. 17, pp. $4419-$ 4430, 2002.

[54] Ma, Z.Y., Sharma, S.R., Mishra, R.S. "Microstructural Modification of As-Cast AlSi-Mg Alloy by Friction Stir Processing”, Metallurgical and materials transactions A, Vol. 37A, pp. 3323-3336, 2006.

[55] Madhusudhan Reddy, G., Mastanaiah, P., Sata Prasad, K. and Mohandas, T. "Microstructure and mechanical property correlations in AA6061 aluminium alloy friction stir welds", Transactions of The Indian Institute of Metals, Vol. 62, No. 1, pp. 49-58, 2009

[56] Mahoney, M.W., Rhodes, C.G., Flintoff, J.G., Spurling, R.A. and Bingel, W.H. “ Properties of riction stir welded $7075 \& 651$ aluminium”, Metallurgical and Materials Transactions A, Vol. 29, No.7, pp. 1955-1964, 1998.

[57] Malarvizhi, S. and Balasubramanian, V. "Effects of Welding Processes and PostWeld Aging Treatment on Fatigue Behavior of AA2219 Aluminium Alloy". Joints Journal of Materials Engineering and Performance, Vol. 20, pp. 359-367, 2011.

[58] Mishra, R.S., Ma, Z.Y. "Friction stir welding and processing", "Materials Science and Engineering R”, Vol. 50, pp. 1-78, 2005.

[59] Montgomery, D. C. "Design and Analysis of Experiments", 5th edition, John Wiley \& Sons, New York, 2001.

[60] Murr, L.E., Li, Y., Flores, R.D., Trillo, E.A., McClure, J.C. "Intercalation vortices and related microstructural features in the friction-stir welding of dissimilar metals", Materials Research Innovations, Vol. 2, pp. 150-163, 1998.

[61] Mustafa Boz. and Adem Kurt. "The influence of stirrer geometry on bonding and mechanical properties in friction stir welding process", Materials and Design, Vol. 25, pp. 343-347, 2004.

[62] Mustafa Kemal Bilici. "Application of Taguchi approach to optimize friction stir spot welding parameters of polypropylene", Materials and Design, Vol. 35, pp. 113-119, 2012.

[63] Nandan, R., DebRoy, T., Bhadeshia, H.K.D.H. "Recent advances in friction-stir welding - Process, weldment structure and properties", Progress in Materials Science, Vol. 53, pp. 980-1023, 2008.

[64] Nandan, R., Roy, C.G., Lienert, T., DebRoy, T. "Numerical simulation of three dimensional heat transfer and plastic flow during friction stir welding of stainless steel", Science and Technology of Welding and Joining, Vol. 11, pp. 526-537, 2006.

[65] Nian, C.Y., Yang, W.H. and Tarng, Y.S. "Optimization of turning operations with multiple performance characteristics", Journal of Materials Processing Technology, Vol. 95, pp. 90-95, 1999.

[66] Oertelt, G., Babu, S.S., David, S. A. and Kenok, E. A. "Effect of thermal cycling of friction stir welds of 2195 aluminium alloy", Welding Journal, pp. 71-79, 2001.

[67] Omar Hatamleh., Preet M Singh., Hamid Garmestanib. "Corrosion susceptibility of peened friction stir welded 7075 aluminum alloy joints", Corrosion Science, Vol. 51, pp. 135-143, 2009.

[68] Paglia, C.S. and Buchheit, R.G. "A look in the corrosion of aluminum alloy friction stir welds",ScriptaMaterialia, Vol.58, pp.383-387, 2008.

[69] Park, S.K., Hong, S.T., Park, J.K., Park, K.Y., Kwon, Y.J. and Son, H.J. "The effect of material locations on the properties of friction stir welding joints of dissimilar 
aluminium alloys", Science and Technology of Welding and Joining, Vol. 15, pp. 331-336, 2010

[70] Peel, M.J., Preuss, M. and Withers, P. J. "Microstructure, mechanical properties and residual stresses as a function of welding speed in AA5083 Friction Stir Welds", Acta Materialia, Vol. 51, pp. 4791-4801, 2003.

[71] Priya, R., Subramanya Sarma, V., Prasad Rao, K. "Effect of post weld heat treatment on the microstructure and tensile properties of dissimilar friction stir welded AA2219 and AA6061alloys", Transactions of The Indian Institute of Metals, Vol. 62, pp. 1119, 2009.

[72] Ren, S.R., Ma, Z.Y. and Chen, L.Q. "Effect of welding parameters on tensile properties and fracture behavior of friction stir welded Al-MgSi alloy", Scripta Materials, Vol. 56, pp. 69-72, 2007.

[73] Rhodes, C.G., Mahoney, M.W., Bingel, W.H., Spurling, R.A. and Bampton, C.C. "Effects of FSW on microstructure of 7075 aluminium", Scripta Materialia, Vol. 36, p.69, 1997.

[74] Robinson, I. B., Collins, F.R. and Dowd, J. D. " Welding high strength aluminium alloys", Welding Journal, pp. 221-228s, 1962.

[75] Saad Ahmed Khodir. and Toshiya Shibayanagi. "Friction Stir Welding of Dissimilar AA2024 and AA7075 Aluminum Alloys", Materials Science and Engineering B, Vol. 148, pp. 82-87, 2008.

[76] Samar Jyoti Kalita. "Microstructure and corrosion properties of diode laser melted friction stir weld of aluminum alloy 2024 T351", Applied Surface Science, Vol. 257, pp. 3985-3997, 2011.

[77] Sato Y.S., Kokawa H., Enmoto M. and Jogan S. "Microstrucrual evolution of 6063 aluminium during friction stir welding" Metallurgical and Materials Transactions A, Vol. 30, No.9, pp. 2429-2437, 1999.

[78] Sato, Y.S., Urata, M. and Kokawa, H. "Parameters controlling microstructure and hardness during friction-stir welding of precipitation-hardenable aluminium alloy 6063”, Metallurgical Material Transactions A, Vol. 33, pp. 625-635, 2002.

[79] Sato, Y.S., Harayama, N., Kokawa, H., Inoue, H., Tadokoro, Y., Tsuge, S. "Evaluation of microstructure and properties in friction stir welded superaustenitic stainless steel", Science and Technology of Welding and Joining, Vol. 14, pp. 202209, 2010

[80] Shanmuga Sundaram, N. and Murugan, N. "Tensile behavior of dissimilar friction stir welded joints of aluminium alloys", Materials and Design, Vol. 31, pp. 4184-4193, 2010.

[81] Shigematsu, I., Kwon, Y.J., Suzuki, K., Imai, T. and Satio, N. "Joining of 5083 and 6061 aluminum alloys by friction stir welding", Journal of Materials Science Letters, Vol. 22, pp. $353-356,2003$.

[82] Srinivasa rao, K. and Prasad, K. "Some studies on Pitting Corrosion of AA2219 alloy and its TIG welds", Transactions of Indian Institute of Metals, vol.56, 2003, pp. 383390.

[83] Stefano Maggiolino. and Chiara Schmid. "Corrosion resistance in FSW and in MIG welding techniques of AA6XXX", journal of materials processing technology, Vol. 197, pp. 237-240, 2008.

[84] Steuwer Peel, M.J. and Withers, P.J. "Dissimilar friction stir welds in AA5083 AA6082: the effect of process parameters on residual stress", Materials Science and Engineering A, Vol. 441, pp. 187 -196, 2006. 
[85] Sung-Hyeon, PARK., Jong-Shin, KIM., Min-Su, HAN., Seong-Jong, KIM. "Corrosion and optimum corrosion protection potential of friction stir welded 5083-O Al alloy for leisure ship", Trans. Nonferrous Met. Soc. China, Vol. 19, pp. 898-903, 2009

[86] Surekha, K., Murty, B.S., Prasad Rao, K. "Effect of processing parameters on the corrosion behaviour of friction stir processed AA2219 aluminum alloy", Solid State Sciences, Volume 11, No. 4, pp. 907-917, 2009.

[87] Tavares, S.M.O., Castro, R.A.S., Richter-Trummer, V., Vilaca, P., Moreira, P.M.G.P., De Castro, P. M. S. T. "Friction stir welding of T- joints with dissimilar aluminium alloys: mechanical joint characterization", Science and Technology of Welding and Joining, Vol. 15, pp. 312-318, 2010.

[88] Thaiping Chen. "Process parameters study on FSW joint of dissimilar metals for aluminum-steel”, Journal of Material Science, Vol. 44, pp. 2573-2580, 2009.

[89] Thomas, W.M., Nicholas, E.D, Needham, J.C, Murch, M.G, TempleSmith, P., Dawes, C.J. "Friction stir butt welding", International Patent No. PCT/GB92/02203, GB Patent No. 9125978.8 (1991), US Patent No. 5,460,317. 1995

[90] Tran, V.X. and Pan, J. "Failure modes of friction stir spot welds in cross-tension specimens of dissimilar aluminium sheets", Science and Technology of Welding and Joining, Vol. 15, pp. 286-292, 2010

[91] Trazil, J. P. and Hood, D. W. "Electron beam welding 2219 aluminium alloy for pressure vessel applications", Welding Journal, September, pp. 395-408s, 1969.

[92] Vijayan, S., Raju, R., Subbaiah, K., Sridhar, N., Rao, S.R.K. "Friction Stir Welding of Al-Mg alloy-Optimization of process parameters using Taguchi Method", Experimental Techniques, Vol.34, No. 5, pp,37-44, 2010.

[93] WajiraMirihanage. and Nanda Munasinghe. "Modification of AA5083 Weld Joint Characteristics", International Symposium of Research Students on Materials Science and Engineering, December 20-22, Chennai, India, 2004.

[94] Weifeng Xu., Jinhe Liu. "Microstructure and pitting corrosion of friction stir welded joints in 2219-O aluminum alloy thick plate", Corrosion Science, Vol. 51, pp. 27432751, 2009.

[95] Weifeng Xu., Jinhe Liu., Hongqiang Zhu. "Pitting corrosion of friction stir welded aluminum alloy thick plate in alkaline chloride solution", Electrochimica Acta, Vol. 55, pp. 2918-2923, 2010.

[96] Xue, P., Ni, D.R., Wang, D., Xiao, B.L., Ma, Z.Y., "Effect of friction stir welding parameters on the microstructure and mechanical properties of the dissimilar $\mathrm{Al}-\mathrm{Cu}$ joints", Materials Science and Engineering A, Vol. 528, pp. 4683-4689, 2011.

[97] Yan Yong, Zhang Da-tong and Qiu Cheng Zhan. "Dissimilar friction stir welding between 5052 aluminum alloy and AZ31 magnesium alloy", Transactions of Nonferrous Metals Society of China, Vol. 20, pp. s619 s623, 2010 